\title{
Pro-apoptotic activity of $\alpha$-bisabolol in preclinical models of primary human acute leukemia cells
}

\author{
Elisabetta Cavalieri', Antonella Rigo ${ }^{2}$, Massimiliano Bonifacio ${ }^{2}$, Alessandra Carcereri de Prati ${ }^{1}$, \\ Emanuele Guardalben ${ }^{2}$, Christian Bergamini ${ }^{3}$, Romana Fato ${ }^{3}$, Giovanni Pizzolo ${ }^{2}$, Hisanori Suzuki ${ }^{1}$ and \\ Fabrizio Vinante $2^{2^{*}}$
}

\begin{abstract}
Background: We previously demonstrated that the plant-derived agent $\alpha$-bisabolol enters cells via lipid rafts, binds to the pro-apoptotic Bcl-2 family protein BID, and may induce apoptosis. Here we studied the activity of $\alpha$ bisabolol in acute leukemia cells.

Methods: We tested ex vivo blasts from 42 acute leukemias (14 Philadelphia-negative and 14 Philadelphia-positive $\mathrm{B}$ acute lymphoid leukemias, $\mathrm{Ph}^{-} / \mathrm{Ph}^{+} \mathrm{B}-\mathrm{ALL} ; 14$ acute myeloid leukemias, AML) for their sensitivity to $\alpha$-bisabolol in 24-hour dose-response assays. Concentrations and time were chosen based on CD34 ${ }^{+}, \mathrm{CD}_{3} 3^{+}$my and normal peripheral blood cell sensitivity to increasing $\alpha$-bisabolol concentrations for up to 120 hours.

Results: A clustering analysis of the sensitivity over 24 hours identified three clusters. Cluster $1(14 \pm 5 \mu \mathrm{M} \alpha$ bisabolol IC $C_{50}$ ) included mainly Ph'B-ALL cells. AML cells were split into cluster 2 and 3 (45 \pm 7 and $65 \pm 5 \mu \mathrm{M}$ $\left.I_{50}\right)$. Ph ${ }^{+} B-A L L$ cells were scattered, but mainly grouped into cluster 2 . All leukemias, including 3 imatinib-resistant cases, were eventually responsive, but a subset of B-ALL cells was fairly sensitive to low $\alpha$-bisabolol concentrations. $\alpha$-bisabolol acted as a pro-apoptotic agent via a direct damage to mitochondrial integrity, which was responsible for the decrease in $\mathrm{NADH}$-supported state 3 respiration and the disruption of the mitochondrial membrane potential.
\end{abstract}

Conclusion: Our study provides the first evidence that $\alpha$-bisabolol is a pro-apoptotic agent for primary human acute leukemia cells.

\section{Background}

$\alpha$-bisabolol is a small oily sesquiterpene alcohol (Figure 1A) that has been demonstrated to have activity against some malignant adherent human and rat cell lines [1] and against spontaneous mammary tumors in HER-2 transgenic mice [2]. We have previously found that it enters cells via lipid-rafts, interacts directly with BID, a pro-apoptotic BH3-only Bcl-2 family protein, and induces apoptosis [3].

Here we test the pro-apoptotic potential of $\alpha$-bisabolol against primary acute leukemia cells, including Philadelphia-negative and -positive $B$ acute lymphoid leukemias $\left(\mathrm{Ph}^{-} / \mathrm{Ph}^{+} \mathrm{B}-\mathrm{ALL}\right)$ and acute myeloid leukemias (AML), and against normal blood white cells and hematopoietic

\footnotetext{
* Correspondence: fabrizio.vinante@univr.it

${ }^{2}$ Department of Medicine, Section of Hematology, University of Verona, Italy Full list of author information is available at the end of the article
}

bone marrow stem cells. Leukemic blasts represent a unique model to study the activity of $\alpha$-bisabolol due to their biology allowing easy manipulation and evaluation. Moreover, acute leukemia treatment in adults is unsatisfactory despite investigations over the past four decades of a wide variety of anti-leukemic agents, refinement of bone marrow transplantation and the development of specific targeted therapy $[4,5]$. There is a particular need for treatments with both high efficacy and low toxicity [6] based on new molecules with mechanisms of action different from conventional drugs. This is especially true for elderly leukemia patients, who represent the majority of cases and have fewer therapeutic options [7]. Likewise, despite the introduction of anti-BCR/ABL tyrosine kinases for the treatment of $\mathrm{Ph}^{+}$leukemias, it seems that identification of novel compounds is perhaps necessary for success in eradicating $\mathrm{Ph}^{+}$cells $[8,9]$.

\section{C) Biomed Central}




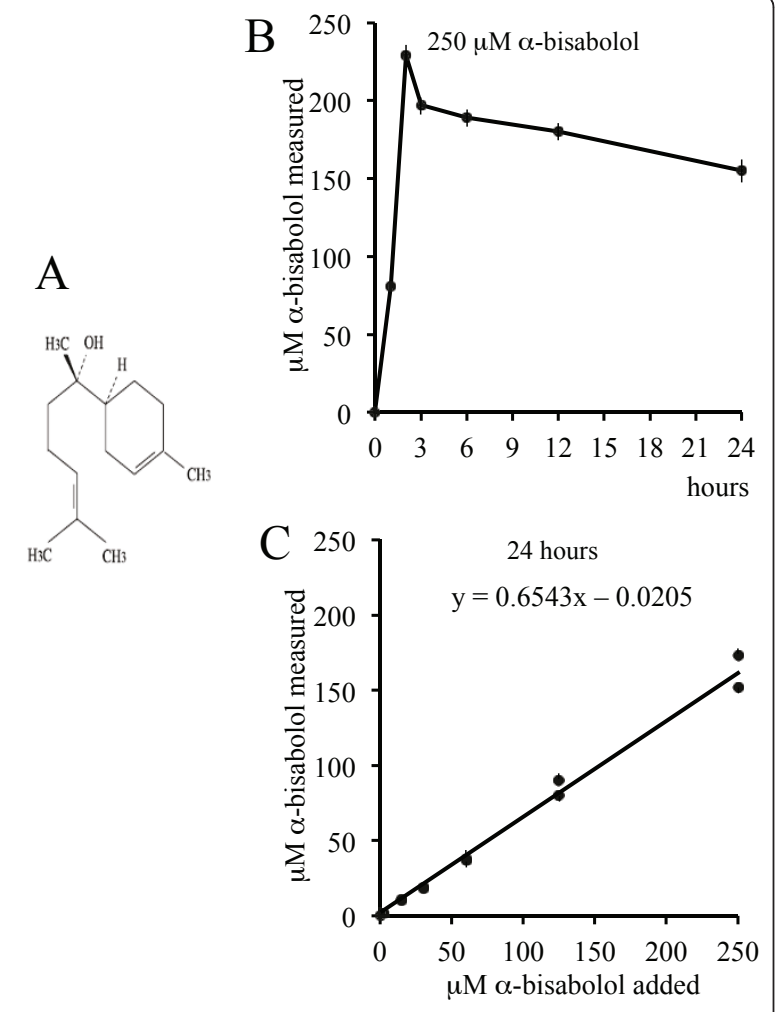

Figure $1 \alpha$-bisabolol structure and solubilization in the culture medium. (A) $\alpha$-bisabolol is a small oily sesquiterpene alcohol with a molecular mass of $222.37 \mathrm{Da}$. (B) $250 \mu \mathrm{M} \alpha$-bisabolol was added to culture medium: concentration raised during the first 3 hours, then lowered to around $65 \%$ of the initially added $\alpha$-bisabolol after 24 hours. (C) By this time, the linear function relating added to measured concentrations of $\alpha$-bisabolol shows that the incremental ratio was 0.65 for 14 evaluations representing a double series of 7 scaled concentrations tested by a RP-HPLC method. Each point is the mean \pm SD of 2 measurements.

The present study shows that $\alpha$-bisabolol enters acute leukemic cells, where it disrupts the mitochondrial membrane potential and triggers apoptosis. Interestingly, $\alpha$-bisabolol seems to be a much more effective agent in some Ph ${ }^{-} \mathrm{B}-\mathrm{ALL}$ cells than in other types of acute leukemias at dosages that spare normal leukocytes and hematopoietic stem cells.

\section{Methods}

\section{Patients and ethical requirements}

Blasts from 28 patients with B-lineage ALL (14 $\mathrm{Ph}^{-}, 14$ $\mathrm{Ph}^{+} \mathrm{B}$-ALL) and 14 with AML diagnosed at our institution, as well as blood and bone marrow cells from five healthy control donors, were collected after written informed consent was obtained, according to Italian law. All cellular studies were approved by the Verona University Hospital ethics committee. Patient characteristics are detailed in Table 1. The diagnosis of B-ALL or AML and their subtypes was based on clinical findings and on established morphological, cytochemical, cytofluorimetric, cytogenetic and molecular features of peripheral blood and bone marrow cells. AML patients received three induction courses according to standard AML treatment $\left(1^{\text {st }}\right.$ course: 3 -day idarubicin +7 -day AraC by continuous i.v. infusion; $2^{\text {nd }}$ course: 3 -day idarubicin + 3-day high-dose AraC; $3^{\text {rd }}$ course: 3-day high-dose AraC). B-ALL patients were treated with induction and maintenance therapy according to the VR95ALL protocol [10], which has been subsequently developed into the GIMEMA 0496 ALL protocol [11]. Young B-ALL patients $(<18$ years) were treated according to a specific pediatric protocol [12]. $\mathrm{Ph}^{+} \mathrm{B}$-ALL patients underwent differential treatment including BCR/ABL TKI. Allogeneic bone marrow transplantation was performed during the first complete remission in four $\mathrm{Ph}^{-} \mathrm{B}$-ALL cases and four $\mathrm{Ph}^{+} \mathrm{B}$-ALL cases.

\section{Cells}

\section{Primary Leukemic cells}

Viable leukemic cells were purified by conventional methods from freshly heparinized peripheral blood with a circulating blast count $\geq 30,000 / \mathrm{mL}$, or from full-substituted bone marrow that was frozen in liquid nitrogen at diagnosis [13]. In all cases frozen cell samples contained $>95 \%$ blasts. Cell viability after thawing was always $>90 \%$, as assessed by trypan blue staining.

\section{Normal cells}

Viable peripheral blood leukocytes [14] and bone marrow cells from - 4 - control donors were treated and used as specified above for leukemic cells.

\section{Cell line}

The imatinib-sensitive $\mathrm{BCR} / \mathrm{ABL}^{+} \mathrm{CML}-\mathrm{T} 1$ cell line (T-lineage blast crisis of human chronic myeloid leukemia, purchased from DSMZ, Braunschweig, DE) was used to perform synergism studies.

\section{Measurement of $\alpha$-bisabolol concentrations in the culture medium}

$\alpha$-bisabolol at a purity $\geq 95 \%$ (GC) was purchased from Sigma-Aldrich, St. Louis, MO. The dose-dependent solubilization of $\alpha$-bisabolol in the culture medium over 24 hours was determined by a reverse-phase high performance liquid chromatography (RP-HPLC) method, developed in the Department of Food Science of Bologna University, Cesena office, Italy. All measurements were performed in duplicate. The $\alpha$-bisabolol concentrations indicated throughout the article represent the calculated soluble fraction in the assay.

\section{Cytotoxicity assays}

Cells derived from patients or normal donors were exposed for 24 hours to $20,40,80$, and $160 \mu \mathrm{M} \alpha$-bisabolol dissolved in ethanol (1:8 in order to minimize 
Table 1 Patients' characteristics.

\begin{tabular}{|c|c|c|c|c|c|c|c|c|}
\hline patient & sex & age & diagnosis & $\begin{array}{c}\text { Karyotype } \\
\text { mol biol }\end{array}$ & therapy* & response ${ }^{\S}$ & relapse & $O S^{\S \S}$ \\
\hline \multicolumn{9}{|c|}{$\mathrm{Ph}^{-} \mathrm{B}-\mathrm{ALL}$} \\
\hline \#01 & M & 22 & B common & normal & $1+2$ & $C R$ & Yes & $29+$ \\
\hline$\# 02$ & M & 40 & Pre-B & NA & $1+2$ & $C R$ & No & $24+$ \\
\hline \#03 & M & 16 & B common & normal & 1 & $C R$ & Yes & 12 \\
\hline$\# 04$ & M & 45 & Pre-B & normal & $1+2$ & $C R$ & No & $38+$ \\
\hline \#05 & $F$ & 53 & B common & hyperdiploid & 1 & $C R$ & No & $71+$ \\
\hline$\# 06$ & $\mathrm{~F}$ & 48 & Pro-B & $\mathrm{t}(4 ; 11)$ & 1 & $C R$ & Yes & 8 \\
\hline$\# 07$ & $F$ & 42 & Pro-B & $\mathrm{t}(4 ; 11)$ & 1 & $C R$ & Yes & 6 \\
\hline$\# 08$ & M & 41 & Pre-B & $t(6 ; 8)$ & 1 & $C R$ & Yes & 19 \\
\hline$\# 09$ & M & 59 & Pro-B & $\mathrm{t}(4 ; 11)$ & 1 & $C R$ & Yes & 10 \\
\hline$\# 10$ & $F$ & 19 & B common & hyperdiploid & 1 & $C R$ & No & $55+$ \\
\hline$\# 11$ & M & 17 & B common & $t(17 ; 22)$ & 3 & $C R$ & No & $9+$ \\
\hline$\# 12$ & $F$ & 53 & B common & NA & 1 & $C R$ & Yes & $13+$ \\
\hline$\# 13$ & $\mathrm{~F}$ & 43 & B common & normal & $1+2$ & $C R$ & Yes & 25 \\
\hline$\# 14$ & $F$ & 17 & B common & normal & 3 & NR & Yes & 4 \\
\hline \multicolumn{9}{|c|}{$\mathrm{Ph}^{+} \mathrm{B}-\mathrm{ALL}$} \\
\hline$\# 01$ & M & 44 & Pre-B & $\begin{array}{l}\text { Ph masked } \\
\text { p210 (Y253H) }\end{array}$ & $I M+D+2$ & $C R$ & No & $12+$ \\
\hline \#02 & $\mathrm{F}$ & 54 & B common & $\begin{array}{l}t(9 ; 22) \\
\text { p210 }\end{array}$ & 1 (pre-IM) & no $C R$ & & 36 \\
\hline$\# 03$ & M & 64 & Pre-B & $\begin{array}{l}\mathrm{t}(9 ; 22) \\
\mathrm{p} 210\end{array}$ & IM & CHR, CCyR & Yes & 9 \\
\hline$\# 04$ & M & 19 & B common & $\begin{array}{c}t(9 ; 22) \\
N A(E 255 V)\end{array}$ & $1+\mathrm{IM}+\mathrm{N}$ & no CHR & & 16 \\
\hline \#05 & M & 40 & Pre-B & $\begin{array}{l}t(9 ; 22),-10 \\
\text { p210 }\end{array}$ & $1+I M+D$ & CHR, CCyR & Yes & 15 \\
\hline \#06 & $\mathrm{F}$ & 38 & Pre-B & $\begin{array}{c}\mathrm{t}(9 ; 22) \\
\text { p190 (T315I) }\end{array}$ & $1+I M+D$ & no CHR & & 9 \\
\hline$\# 07$ & M & 17 & B common & $\begin{array}{l}\mathrm{t}(9 ; 22) \\
\mathrm{p} 210\end{array}$ & $1($ pre-IM) +2 & $C R$ & Yes & 11 \\
\hline$\# 08$ & M & 70 & Pre-B & $\begin{array}{l}\mathrm{t}(9 ; 22) \\
\text { NA }\end{array}$ & 5 (pre-IM) & no $C R$ & & 1 \\
\hline$\# 09$ & M & 35 & B common & $\begin{array}{l}\mathrm{t}(9 ; 22) \text {, del(6) } \\
\text { p190 }\end{array}$ & $1+I M+2$ & CCyR, MMR & No & $46+$ \\
\hline \#10 & M & 63 & B common & $\begin{array}{c}\mathrm{t}(9 ; 22) \\
\mathrm{p} 190\end{array}$ & $\mathrm{IM}+\mathrm{CS}$ & CCyR, MMR & No & $15+$ \\
\hline$\# 11$ & $F$ & 75 & B common & hyperdiploid, t(9;22), NA & 5 (pre-IM) & no $C R$ & & 14 \\
\hline$\# 12$ & M & 89 & Pre-B & $\begin{array}{l}\mathrm{t}(9 ; 22) \\
\text { p190 }\end{array}$ & $\mathrm{IM}$ & CCyR, MMR & Yes & $22+$ \\
\hline$\# 13$ & $\mathrm{~F}$ & 27 & B common & $\begin{array}{l}t(9 ; 22) \\
\text { p190 }\end{array}$ & $1+\mathrm{IM}$ & no $\mathrm{CHR}$ & & 10 \\
\hline$\# 14$ & M & 28 & B common & $\begin{array}{l}\mathrm{t}(9 ; 22) \\
\mathrm{p} 190\end{array}$ & $1+I M+2$ & $C R$ & Yes & 37 \\
\hline \multicolumn{9}{|c|}{ AML } \\
\hline \#01 & M & 59 & M2 & $+4,+8$ & 4 & $P R$ & Yes & 7 \\
\hline$\# 02$ & M & 46 & MO & NA & 4 & $\mathrm{TD}$ & & 1 \\
\hline \#03 & $\mathrm{F}$ & 37 & M4 & $\operatorname{del}(X)(p 21)$ & 4 & $C R$ & No & $167+$ \\
\hline$\# 04$ & $\mathrm{~F}$ & 47 & M2 & normal & 4 & $N R$ & Yes & 20 \\
\hline \#05 & $F$ & 70 & M4 Eo & $\operatorname{inv}(16)$ & 4 & NR & no $C R$ & 6 \\
\hline \#06 & M & 74 & M4 & normal & 5 & & & 2 \\
\hline$\# 07$ & M & 62 & M4 & normal & 4 & $N R$ & no $C R$ & 5 \\
\hline \#08 & M & 69 & M4 Eo & NA & 5 & & & 5 \\
\hline$\# 09$ & M & 60 & M2 & -7 & 4 & $C R$ & No & $38+$ \\
\hline$\# 10$ & M & 83 & M2 & NA & 5 & & & 3 \\
\hline
\end{tabular}


Table 1 Patients' characteristics. (Continued)

\begin{tabular}{|c|c|c|c|c|c|c|c|c|}
\hline$\# 11$ & M & 88 & M2 & NA & 5 & & & 1 \\
\hline$\# 12$ & F & 79 & MO & normal & 5 & & & 9 \\
\hline \#13 & M & 52 & M4 & normal & 4 & $C R$ & No & $24+$ \\
\hline \#14 & $F$ & 61 & M2 & $\mathrm{t}(11 ; 22)$ & 4 & $C R$ & Yes & 11 \\
\hline
\end{tabular}

*Therapy: 1 = ALLVR589 protocol [10] or subsequent GIMEMA protocol LAL0496 [11]; 2 = allogeneic bone marrow transplantation; 3 = AIEOP-BFM-ALL 2000 protocol [12]; 4 = AML standard treatment (see Matherials and Methods); 5 = supportive care (hydroxicarbamide, blood transfusions etc); CS = corticosteroid; $\mathrm{IM}=$ imatinib; $\mathrm{D}=$ dasatinib; $\mathrm{N}=$ nilotinib

${ }^{\S} \mathrm{NA}=$ not avalaible; $\mathrm{CR}=$ complete remission; $\mathrm{PR}=$ partial remission; $\mathrm{NR}=$ non-responder; $\mathrm{TD}=$ toxic death; $\mathrm{CHR}=$ complete hematologic remission; $\mathrm{CCyR}=$ complete cytogenetic remission; MMR = major molecular remission (>3 log reduction bcr/abl ratio)

$\S \S+$ = ongoing follow-up

drug volumes), and when appropriate to $3 \mu \mathrm{M}$ imatinib mesylate (Novartis, Basel, $\mathrm{CH}$ ), representative of the in vivo active concentration. All cytotoxicity tests were performed in triplicate.

\section{Homogeneous cell populations}

A lactate dehydrogenase (LDH) release assay was conducted as follows. Thawed cells were resuspended in RPMI-1640 (Lonza, Basel, CH) supplemented with 10\% heat-inactivated fetal bovine serum (FBS, Lonza), $50 \mathrm{U} / \mathrm{mL}$ penicillin and $50 \mu \mathrm{g} / \mathrm{mL}$ streptomycin (complete medium, $\mathrm{CM}$ ), seeded at a density of $2 \times 10^{6} \mathrm{cell} / \mathrm{mL}$ and incubated at $37^{\circ} \mathrm{C}$ in $5 \% \mathrm{CO}_{2}$. After 24 hours, the cells were treated with $\alpha$-bisabolol (or ethanol as a vehicle control) as specified above. Cytotoxicity was determined using the Cytotoxicity Detection Kit ${ }^{\text {PLUS }}$ according to the manufacturer's recommendations (Roche, Mannheim, DE). LDH leakage was measured as the ratio of treatment-induced LDH to spontaneous LDH release. $\alpha$-bisabolol and imatinib mesylate data were reported as the percent cytotoxicity for treated compared to untreated cells and plotted as dose-response curves over 24 hours. The half maximal inhibitory concentration $\left(\mathrm{IC}_{50}\right)$ was determined when appropriate.

\section{Heterogeneous cell populations}

The absolute counts of normal leukocytes sub-populations were measured with TruCOUNT tubes (Becton Dickinson, San Jose, CA) by polychromatic flow cytometry according to the manufacturer's instructions with minor modifications. Peripheral blood and bone marrow cells were cultured with $\alpha$-bisabolol for 24, 48, 72, 96 and 120 hours. At the end of the culture, $200 \mu \mathrm{L}$ of sample, a mixture of antibodies (CD45 APC-H7, CD3 PECy7, CD19 PE, CD14 APC for peripheral blood and CD45 APC-H7, CD34 PE, CD33 PE-Cy7 for bone marrow) and 7-amino-actinomycin D (all reagents from Becton Dickinson) for dead cells exclusion were added to the TruCOUNT tubes. After a 15-minute incubation at room temperature, $1 \mathrm{~mL}$ lysing reagent (Biosource, Nivelles, $\mathrm{BE})$ was added for 10 minutes. A total of 40,000 beads were acquired on a FACSCanto cytometer (Becton Dickinson). A sequential Boolean gating strategy was used to accurately enumerate different populations [15].

\section{Cytotoxicity data hierarchical clustering analysis}

To generate a classification based on $\alpha$-bisabolol sensitivity, samples were grouped using the complete linkage hierarchical clustering algorithm available in the MultiExperiment Viewer (MeV, version 4.3 - http://www.tm4. org $/ \mathrm{mev} /$ ). A heat map for sensitivity was derived using the percentage data for mortality after adding $\alpha$-bisabolol with respect to spontaneous mortality at the same time.

\section{Synergism studies}

The interactions between imatinib mesylate and $\alpha$-bisabolol were analyzed according to the median-effect method of Chou and Talalay [16] using the CalcuSyn Software (Biosoft, Cambridge, UK). The mean combination index (CI) values, based on constant drug ratios, were assessed with the following interpretation: $\mathrm{CI}>1$, antagonistic effect; $\mathrm{CI}=1$, additive effect; $\mathrm{CI}<1$, synergistic effect. Combination data were depicted as CI $v s$. fraction affected $(\mathrm{Fa})$ plots, defining the $\mathrm{CI}$ variability by the sequential deletion analysis method. The cytotoxicity was evaluated as described above.

\section{Western blot analysis}

Cells were homogenized at $4^{\circ} \mathrm{C}$ in $50 \mathrm{mM}$ Tris- $\mathrm{HCl}$ (pH 8) containing 0.1\% Nonidet-P40 (NP-40), $200 \mathrm{mM}$ $\mathrm{KCl}, 2 \mathrm{mM} \mathrm{MgCl}$, $50 \mu \mathrm{M} \mathrm{ZnCl}_{2}, 2 \mathrm{mM}$ DTT, and protease inhibitors $[1 \mathrm{mM}$ phenylmethylsulfonyl fluoride (PMSF), $1 \mathrm{mg} / \mathrm{mL}$ leupeptin, and $1 \mathrm{mg} / \mathrm{mL}$ antipain]. Aliquots of the homogenates ( $40 \mu \mathrm{g}$ total protein/lane) were loaded on SDS-polyacrylamide gels at the appropriate concentrations. Electrophoresis was performed at $100 \mathrm{~V}$ with a running buffer containing $0.25 \mathrm{M}$ Tris$\mathrm{HCl}$ ( $\mathrm{pH}$ 8.3), $1.92 \mathrm{M}$ glycine, and 1\% SDS. The resolved proteins were electroblotted onto a nitrocellulose membrane using the iBlot ${ }^{\mathrm{TM}}$ system (Invitrogen, Carlsbad, CA). Membranes were then incubated with a mouse monoclonal IgG antibody to poly(ADP-ribose) polymerase (PARP) (Zymed, South San Francisco, CA), with a rabbit polyclonal IgG antibody to BID (Cell Signaling Technology, Danvers, MA) or with a rabbit polyclonal IgG antibody to $\alpha$-tubulin (Cell Signaling Technology). The membranes were then washed and incubated with 
an anti-mouse or anti-rabbit IgG peroxidase-conjugated antibody (Cell Signaling Technology). The blots were washed again and then incubated with enhanced chemiluminescent detection reagents (Immun-Star ${ }^{\mathrm{TM}}$ WesternC ${ }^{\text {TM }}$ Kit, Bio-Rad, Hercules, CA) according to the manufacturer's instructions. Proteins were detected using the ChemiDoc XRS Imaging System (Bio-Rad).

\section{Cytosolic and mitochondrial fraction preparation}

Cell pellets were suspended in $100 \mu \mathrm{L}$ of solution containing $10 \mathrm{mM} \mathrm{NaCl}, 1.5 \mathrm{mM} \mathrm{MgCl}, 10 \mathrm{mM}$ Tris- $\mathrm{HCl}$, $\mathrm{pH} 7.5,1 \mathrm{mM}$ sodium orthovanadate, and complete EDTA-free protease inhibitor cocktail (Boehringer, Mannheim, DE). Cells were then chilled on ice for 10 minutes and gently lysed by adding $0.3 \%(\mathrm{v} / \mathrm{v}) \mathrm{NP}-40$. In order to restore an isotonic environment, a solution containing $525 \mathrm{mM}$ mannitol, $175 \mathrm{mM}$ sucrose, $12.5 \mathrm{mM}$ Tris- $\mathrm{HCl}$, $\mathrm{pH}$ 7.5, $2.5 \mathrm{mM}$ EDTA, and protease inhibitor cocktail was added. Lysates were first centrifuged at $600 \times g$ at $4^{\circ}$ $\mathrm{C}$ in order to remove nuclei and then the supernatants were centrifugated at $17,000 \times g$ for 30 minutes at $4^{\circ} \mathrm{C}$. The obtained supernatants were collected and used as the cytosolic fraction. The pellets, that contained mitochondria, were washed once with the same buffer and then were resuspended in sample buffer. The cytosolic and the mitochondrial fractions were separated on a $15 \%$ SDS-PAGE and probed using a rabbit polyclonal IgG antibody to BID (Cell Signaling Technology). Then, the membrane with the cytosolic and mitochondrial fractions were probed with a rabbit polyclonal IgG antibody to $\alpha$ tubulin (Cell Signaling Technology) and with a mouse monoclonal IgG antibody to Hsp60 (Abcam, Cambridge, $\mathrm{UK})$, respectively.

\section{Cell permeabilization}

Leukemic cells and normal lymphocytes were centrifuged $(10$ minutes, $200 \times g)$ and washed with ice cold buffer A (250 mM sucrose, $20 \mathrm{mM}$ HEPES, $10 \mathrm{mM} \mathrm{MgCl}_{2}-\mathrm{pH}$ 7.1). The pellet was resuspended in $2 \mathrm{~mL}$ of buffer A containing $80 \mu \mathrm{g}$ of digitonin. After a 1-minute incubation on ice, $8 \mathrm{~mL}$ of buffer A were added and cells were centrifuged ( 3 minutes, $400 \times g$ ). The pellet was resuspended in $100 \mu \mathrm{L}$ buffer A containing $1 \mathrm{mM}$ ADP, $2 \mathrm{mM} \mathrm{KH}_{2} \mathrm{PO}_{3}$ (respiration buffer) and immediately used for the polarographic assay. Cell number and permeabilization was measured by the trypan blue exclusion method.

\section{Oxygen consumption}

Permeabilized leukemic cells and lymphocytes were assayed for oxygen consumption at $30^{\circ} \mathrm{C}$ using a thermostatically controlled oxygraph and Clark electrode. Cells were incubated for 10 minutes in respiration buffer at $30^{\circ}$ $\mathrm{C}$ in the presence or absence of $3 \mu \mathrm{M} \alpha$-bisabolol. Mitochondrial respiration (state 3 respiration) was started by adding $5 \mathrm{mM}$ glutamate plus malate $(\mathrm{G} / \mathrm{M})$ and $5 \mathrm{mM}$ succinate plus glycerol-3-phosphate (S/G3P), which are complex I and complex III/glycerol-3-phosphate dehydrogenase substrates, respectively. The maximal respiration rate (uncoupled respiration) was empirically determined by the addition of $200 \mathrm{nM}$ carbonylcyanide-4- (trifluoromethoxy)-phenylhydrazone (FCCP). Oxygen consumption was completely inhibited by adding $4 \mu \mathrm{M}$ antimycin $\mathrm{A}$ at the end of the experiments [17].

\section{Mitochondrial membrane potential evaluation}

Cells resuspended in CM at $1 \times 10^{6} / \mathrm{mL}$ were treated with $40 \mu \mathrm{M} \alpha$-bisabolol for 3 or 5 hours at $37^{\circ} \mathrm{C}$. They were then washed with pre-warmed $\mathrm{CM}, 4 \mu \mathrm{M}$ of the potential sensitive dye JC-1 (5, ', $6,6^{\prime}$-tetra-chloro1,1',3,3'-tetra-ethyl-benz-imidazolyl-carbocyanine iodide, Molecular Probes, Eugene, OR) was added, and they were then placed back into the incubator. After 30 minutes they were washed twice with pre-warmed PBS. An aliquot of each sample was spotted onto a slide, mounted with a coverslip and immediately recorded by an Axio Observer inverted microscope (Zeiss, Gottingen, $\mathrm{DE}$ ). Visualization of JC-1 monomers (green fluorescence) and JC-1 aggregates (red fluorescence) was done using filter sets for fluorescein and rhodamine dyes (emission 488 and $550 \mathrm{~nm}$ respectively). Image captures of random fields using fixed imaging parameters were performed, and previously unviewed areas of cells were captured to avoid photobleaching [18]. Image analysis was done using Axiovision 3 software. The other aliquot of each sample was resuspended in PBS and analyzed using a FACSCalibur cytometer (Becton Dickinson) equipped with a $488 \mathrm{~nm}$ argon laser. The emission of JC-1 monomers was detected in Fl-1 using a 530/30 nm bandpass filter, and JC-1 aggregates were detected in Fl2 using a 585/42 nm bandpass filter. FlowJo 8.8.2 software (Tree Star, Ashland, OR) was used to analyze data [19].

\section{DNA ladder}

For internucleosomal DNA laddering analysis, $5 \times 10^{6}$ cells were resuspended in $0.3 \mathrm{~mL}$ of culture medium containing $10 \% \mathrm{FBS}$ and incubated for 90 minutes at $65^{\circ}$ $\mathrm{C}$ and then overnight at $37^{\circ} \mathrm{C}$ in the presence of $0.4 \mathrm{M}$ $\mathrm{NaCl}, 5 \mathrm{mM}$ Tris- $\mathrm{HCl}$ (pH 8), 2 mM EDTA, 4\% SDS and $2 \mathrm{mg} / \mathrm{mL}$ proteinase $\mathrm{K}$. The lysates were brought to a final concentration of $1.58 \mathrm{M} \mathrm{NaCl}$ and centrifuged twice for 10 minutes at $6,000 \times g$ to separate the DNA fragments from intact DNA. The supernatants were recovered, and DNA was precipitated by the addition of three volumes of absolute ethanol at $-80^{\circ} \mathrm{C}$ for 1 hour. The DNA pellets were recovered by microcentrifugation $(10$ minutes, $12,000 \times g)$ and resuspended in a minimal volume of $40 \mu \mathrm{l}$ of $10 \mathrm{mM}$ Tris- $\mathrm{HCl}(\mathrm{pH}$ 7.4), $1 \mathrm{mM}$ 
EDTA, and $1 \mathrm{mg} / \mathrm{mL}$ DNase-free ribonuclease A. Aliquots of $5 \mu \mathrm{g}$ of DNA were then loaded onto a $1 \%$ agarose gel containing $0.25 \mu \mathrm{g} / \mathrm{mL}$ ethidium bromide. After electrophoresis, the DNA was visualized by UV light using the ChemiDoc XRS Imaging System (Bio-Rad).

\section{Statistics}

Student's t-test for means, chi-squared tests, MannWhitney $\mathrm{U}$ test and Kruskall-Wallis analysis of variance by ranks were considered significant for $p$ values $<0.05$. The 24-hour $\mathrm{IC}_{50}$ was approximated by using mean cytotoxicity data in the different groups (according to diagnosis or clustering-based analysis).

\section{Results}

\section{$\alpha$-bisabolol concentrations in the culture medium}

Due to the lipophilic properties of $\alpha$-bisabolol, a preliminary evaluation was performed of the dose-dependent solubilization in the culture medium over 24 hours by a RP-HPLC method. The addition of $\alpha$-bisabolol at time 0 was followed by a rapid increase of the measured concentrations during the first 3 hours. After 24 hours, concentrations may be considered roughly constant, though with a slightly downward trend (Figure 1B). A double series of 7 determinations corresponding to $0,3,15,30$, $60,125,250 \mu \mathrm{M} \alpha$-bisabolol added to medium gave a linear function with a 0.65 incremental ratio (Figure $1 C$ ), indicating that, after 24 hours, around $65 \%$ of the $\alpha$-bisabolol added was actually measured in the culture medium.

\section{$\alpha$-bisabolol cytotoxicity in normal peripheral blood cells}

The viability of normal blood cells was evaluated after different times and doses of exposure to $\alpha$-bisabolol. The cytotoxicity increased in a dose- and time-dependent manner. Figure 2A depicts the sensitivity to increasing doses of $\alpha$-bisabolol for up to 120 hours in each different blood cell subpopulation. T lymphocytes, which were far less sensitive to $\alpha$-bisabolol than B-lymphocytes, monocytes and neutrophils, had a 24-hour $\mathrm{IC}_{50}$ of $59 \pm 7 \mu \mathrm{M}$ and were only marginally sensitive to $40 \mu \mathrm{M} \alpha$-bisabolol over 120 hours.

\section{$\alpha$-bisabolol cytotoxicity in normal counterparts of acute leukemia cells}

Figure 2B depicts the sensitivity to $\alpha$-bisabolol in CD33 ${ }^{+}$my and $\mathrm{CD}_{3} 4^{+} / 33^{+}$or $\mathrm{CD} 34^{+} / 19^{+}$cells from 5 normal bone marrow samples. These subpopulations were assumed to represent the normal counterpart of acute leukemia blasts and the hematopoietic compartment that is responsible for bone marrow renewal and, eventually, drug toxicity. The 24-hour $\alpha$-bisabolol $\mathrm{IC}_{50}$ was $95 \pm 7$ and $62 \pm 9 \mu \mathrm{M}$ in $\mathrm{CD}_{3}{ }^{+} \mathrm{my}$ and $\mathrm{CD} 34^{+}$cells, respectively $(p<0.05)$. By contrast, no difference was

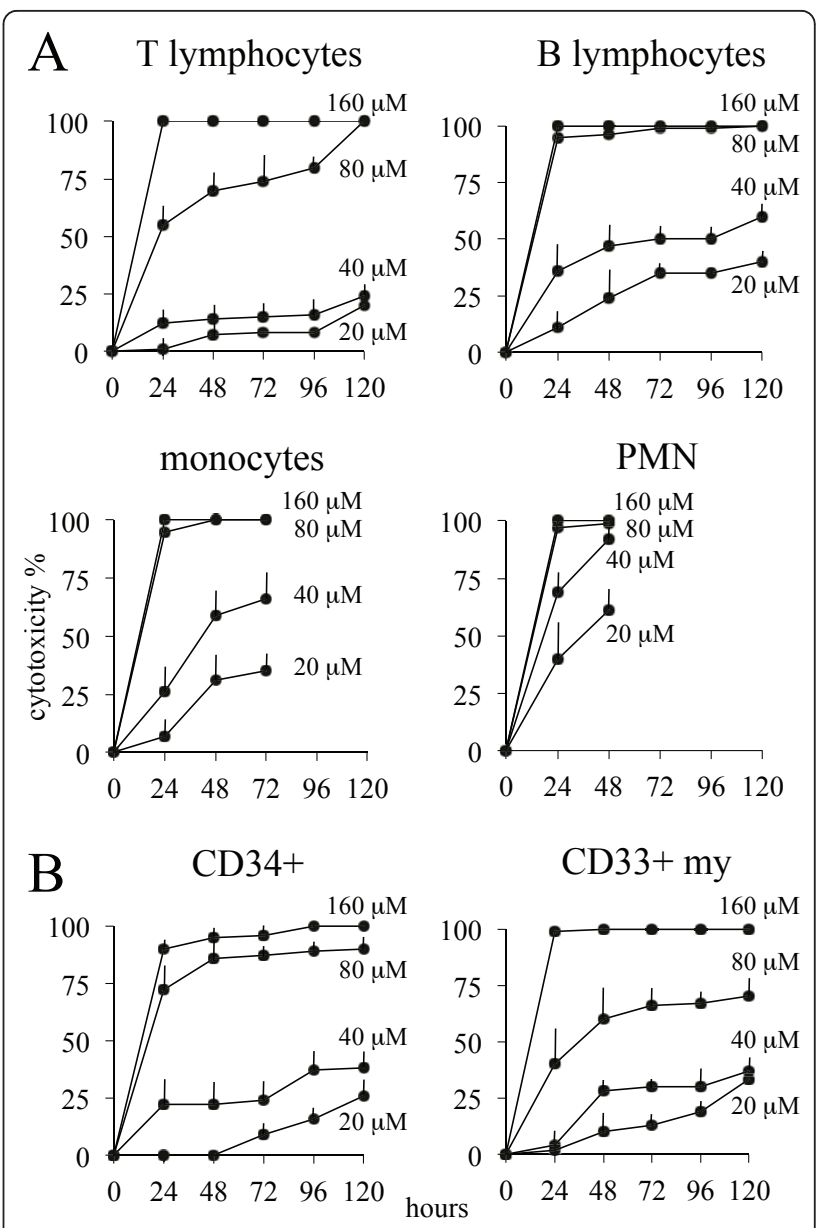

Figure 2 Cytotoxicity of $\alpha$-bisabolol in normal hematologic cells. (A) Peripheral blood cells. (B) Bone marrow stem cells. Timeand dose-response curves between 20 and $160 \mu \mathrm{M} \alpha$-bisabolol in the 120-hour cytotoxicity assays. Means \pm SD of 5 normal donors are depicted.

observed between $\mathrm{CD} 34^{+} / 33^{+}$and $\mathrm{CD} 34^{+} / 19^{+}$cells (64 \pm 6 and $63 \pm 4 \mu \mathrm{M} \mathrm{IC} \mathrm{I}_{50}$, respectively).

$\alpha$-bisabolol cytotoxicity in primary acute leukemia cells by diagnosis

Based on these data from normal cells, we performed $e x$ vivo dose-response (20, 4080 , and $160 \mu \mathrm{M} \alpha$-bisabolol) cytotoxicity assays at 24 hours in 42 different samples of leukemic cells (14 $\mathrm{Ph}^{-} \mathrm{B}-\mathrm{ALL}, 14 \mathrm{Ph}^{+} \mathrm{B}-\mathrm{ALL}, 14 \mathrm{AML}$ ) obtained from patients before any treatment. Table 1 summarizes the main patients' characteristics. Table 2 shows the results of the cytoxicity assays as mean $\pm \mathrm{SD}$ after 24 hours of exposure to different concentrations of $\alpha$-bisabolol, and Figure 3A depicts the corresponding dose-response curves for $\mathrm{Ph}^{-} \mathrm{B}-\mathrm{ALL}, \mathrm{Ph}^{+} \mathrm{B}$-ALL, and AML cells. The 24-hour dose-response assays showed that $\alpha$-bisabolol was cytotoxic to primary $\mathrm{Ph}{ }^{-} \mathrm{B}$-ALL cells $\left(33 \pm 15 \mu \mathrm{M}\left(\mathrm{IC}_{50}\right)\right.$. Though less sensitive, $\mathrm{Ph}^{+} \mathrm{B}$-ALL, 
Table $2 \alpha$-bisabolol cytotoxicity in acute leukemia cells and in their normal counterparts (\% mean values \pm SD according to $\alpha$-bisabolol concentration).

\begin{tabular}{cccccccc}
\hline$\mu \mathrm{M} \alpha$-bisabolol & $\mathbf{2 0}$ & $\mathbf{4 0}$ & $\mathbf{8 0}$ & $\mathbf{1 6 0}$ & $\mathrm{IC}_{\mathbf{5 0}}$ & $\boldsymbol{p}$ \\
\hline Ph-B-ALL & 14 & $37 \pm 36$ & $55 \pm 37$ & $87 \pm 12$ & 100 & $33 \pm 15$ & $<\mathbf{0 . 0 5}$ \\
& & & & & & & $\mathbf{n s}$ \\
$\mathrm{Ph}^{+} \mathrm{B}-\mathrm{ALL}$ & 14 & $2 \pm 19$ & $42 \pm 28$ & $81 \pm 17$ & $98 \pm 2$ & $46 \pm 11$ & \\
$\mathrm{AML}$ & 14 & $10 \pm 9$ & $32 \pm 21$ & $72 \pm 11$ & $96 \pm 4$ & $54 \pm 8$ & \\
\hline cluster 1 & 8 & $72 \pm 24$ & $94 \pm 6$ & $99 \pm 1$ & 100 & $14 \pm 5$ & $<\mathbf{0 . 0 5}$ \\
cluster 2 & 19 & $17 \pm 9$ & $44 \pm 14$ & $77 \pm 15$ & $97 \pm 3$ & $45 \pm 7$ & \\
cluster 3 & $15^{*}$ & $3 \pm 3$ & $14 \pm 8$ & $73 \pm 14$ & $98 \pm 2$ & $65 \pm 5$ & \\
& $17^{\S}$ & $2 \pm 3$ & $14 \pm 8$ & $71 \pm 16$ & $97 \pm 3$ & $64 \pm 5$ & \\
\hline CD34 $^{+}$ & 5 & $1 \pm 2$ & $22 \pm 19$ & $72 \pm 35$ & $98 \pm 1$ & $62 \pm 9$ & $\boldsymbol{n s}$ \\
CD33 $^{+}$my & 5 & $2 \pm 2$ & $4 \pm 3$ & $40 \pm 39$ & $99 \pm 1$ & $95 \pm 7$ & \\
\hline
\end{tabular}

*acute leukemia samples.

${ }^{\S} 15$ acute leukemias plus $\mathrm{CD} 34^{+}$and $\mathrm{CD} 33^{+}$my samples. including $\mathrm{Ph}^{+}$-cells resistant to imatinib mesylate, and AML cells were also killed ( $46 \pm 11$ and $54 \pm 8 \mu \mathrm{M} \mathrm{IC} \mathrm{C}_{50}$, respectively; $p<0.05$ compared to $\left.\mathrm{Ph}^{-} \mathrm{ALL}\right)$. Thus, $\alpha-$ bisabolol is a pro-apoptotic agent for acute leukemia cells ex vivo, particularly for PhB-ALL.

\section{$\alpha$-bisabolol cytotoxicity on primary leukemic cells by clustering analysis}

We generated a cytotoxicity-based classification of our leukemic samples using the complete linkage hierarchical clustering algorithm available in MultiExperiment Viewer. As shown in Figure 3B, clustering analysis identified three main groups $(p<0.05)$ by comparing differences among experimental samples with regard to responsiveness to apoptotic signals induced by $\alpha$-bisabolol. The group with the highest sensitivity to $\alpha$-bisabolol (cluster 1: $14 \pm 5 \mu \mathrm{M} \mathrm{IC}{ }_{50}$ ) included $2 \mathrm{Ph}^{+}$and $6 \mathrm{Ph}^{-}$ B-ALL cases. Thus, a proportion of the Ph ${ }^{-} \mathrm{B}-\mathrm{ALL}$ cases

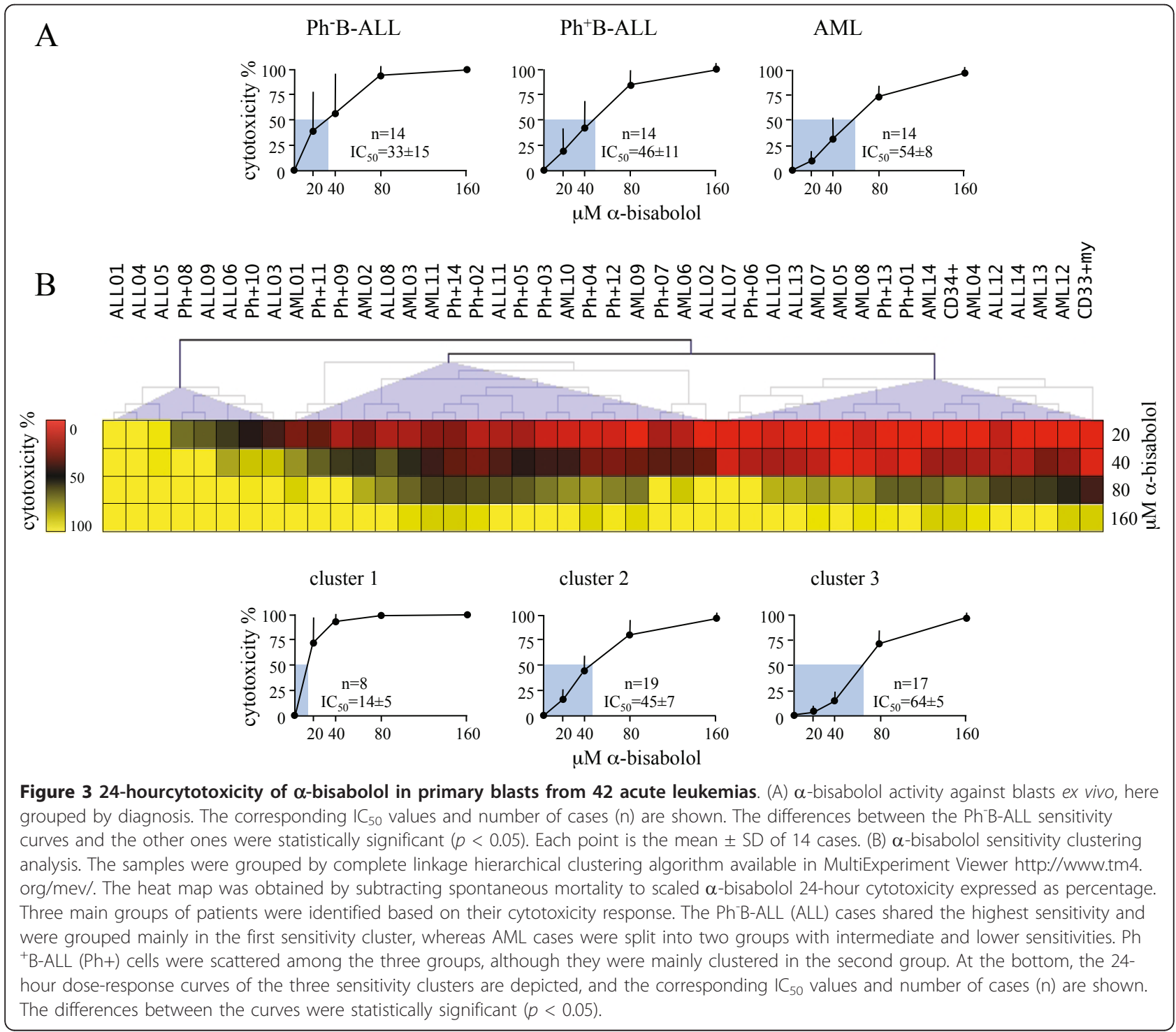




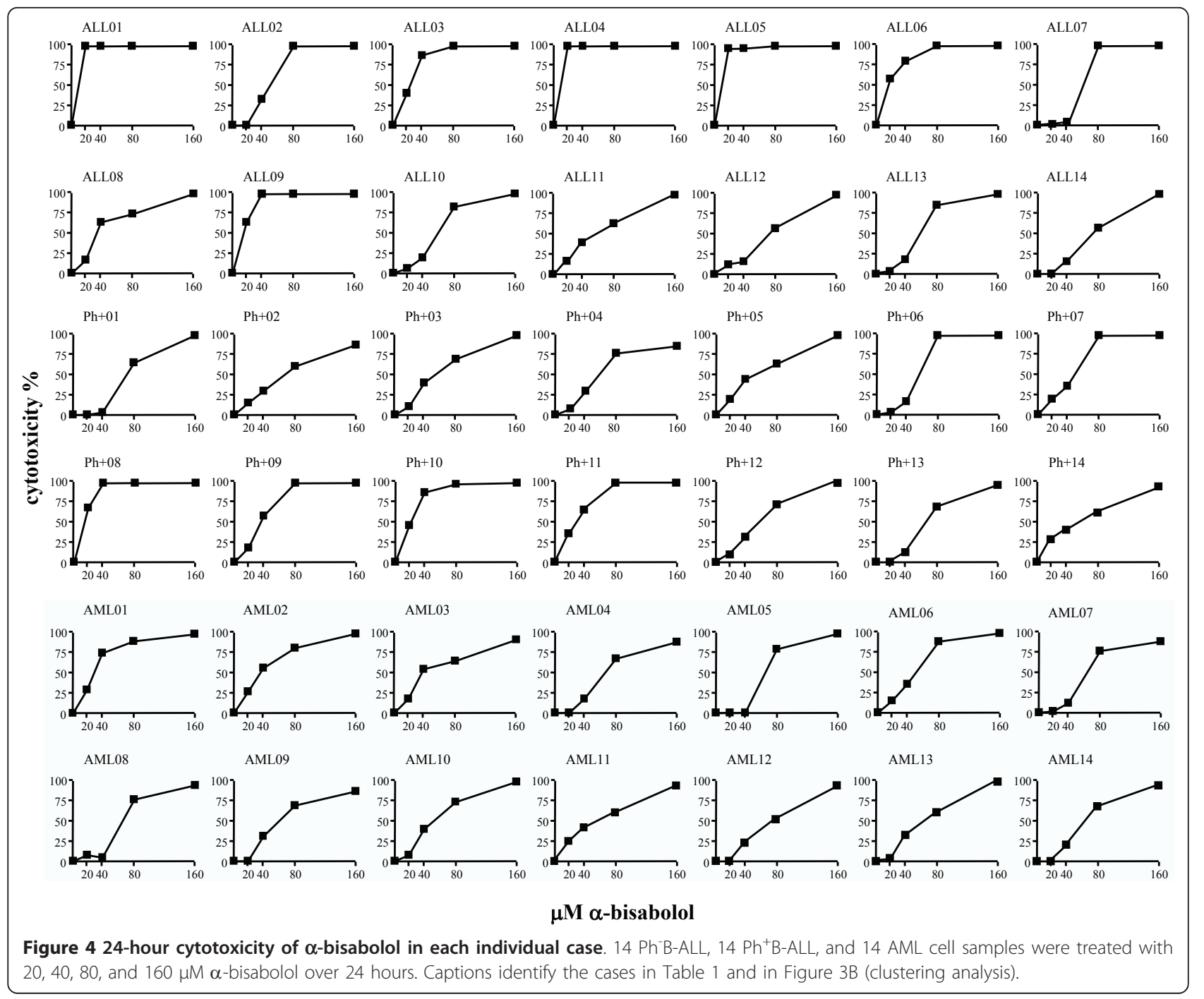

shared a high sensitivity to $\alpha$-bisabolol, although some other $\mathrm{Ph}^{-} \mathrm{B}$-ALL were scattered over different sensitivity groups. The AML cases were split into two groups with intermediate (cluster 2: $45 \pm 7 \mu \mathrm{M} \mathrm{IC}_{50} ; 7$ AML cases) and lower (cluster 3: $65 \pm 5 \mu \mathrm{M} \mathrm{IC}_{50}$; $7 \mathrm{AML}$ cases) sensitivity. Unlike $\mathrm{Ph}{ }^{-} \mathrm{B}-\mathrm{ALL}, \mathrm{AML}$ cases as a whole were less sensitive to $\alpha$-bisabolol. The $\mathrm{Ph}^{+} \mathrm{B}$-ALL cases were scattered all over the three groups but were mainly clustered with intermediate sensitivity AML. Interestingly, introducing both $\mathrm{CD}_{34}{ }^{+}$and $\mathrm{CD} 33^{+}$my cell sensitivity to $\alpha$-bisabolol (as the mean value of 5 cases) in clustering analysis made it evident that ALL cells as a whole were more sensitive to $\alpha$-bisabolol than their normal counterpart (grouped into cluster 3 among less sensitive cells). This analysis demonstrated that some $\mathrm{Ph}^{-} \mathrm{B}$-ALL cases may be highly sensitive to the apoptotic mechanisms activated by $\alpha$-bisabolol and indicated that the $\mathrm{Ph}^{+} \mathrm{B}$ ALL cases and especially the AML cases (these latter showing a bimodal sensitivity) may well be characterized by variable degrees of resistance to these mechanisms. Still, all leukemia cases were eventually responsive to 65 $\mu \mathrm{M} \alpha$-bisabolol for 24 hours (Table 2). In Figure 4, the dose-response assays for each case are depicted.

\section{$\alpha$-bisabolol plus imatinib mesylate in cells bearing} mutated or non-mutated BCR/ABL

$\alpha$-bisabolol was active against $\mathrm{Ph}^{+} \mathrm{B}$-ALL cells (24-hour $\mathrm{IC}_{50}$ was $46 \pm 11 \mu \mathrm{M}$; Figure 3 ). We wondered if $\alpha$-bisabolol and imatinib mesylate had synergistic effects. As shown in Figure 5A cells from case $\mathrm{Ph}^{+} \mathrm{B}$-ALL \#04 (carrying the E255V mutation, Table 1) were primarily resistant to imatinib mesylate and showed similar ex vivo cytotoxicity when treated with either $\alpha$-bisabolol (20, 4080 , and 160 $\mu \mathrm{M}$ for 24 hours) alone or $\alpha$-bisabolol associated with imatinib mesylate ( $3 \mu \mathrm{M}$ for 24 hours representative of in vivo effective concentration). In contrast, cells sensitive to 


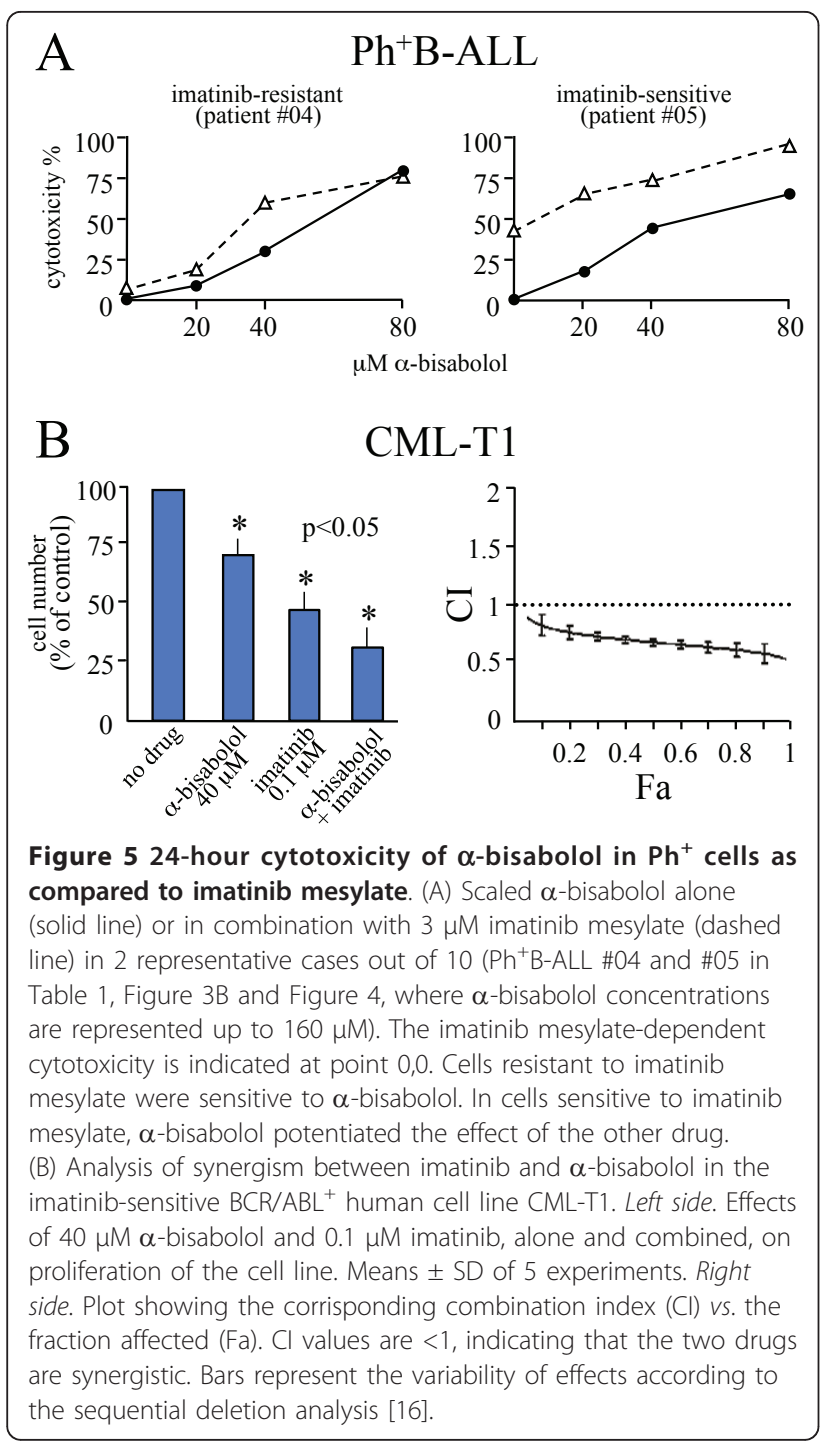

imatinib mesylate shared a significant increase in cytotoxicity to $\alpha$-bisabolol. For instance, cells from patient $\mathrm{Ph}^{+} \mathrm{B}$ ALL \#05 (Table 1) shifted from 40\% cytotoxicity with $40 \mu \mathrm{M} \alpha$-bisabolol alone to $75 \%$ with $\alpha$-bisabolol plus imatinib mesylate. This may suggest that the presence of BCR/ ABL tyrosine kinase activity in a cell reduces the effectiveness of $\alpha$-bisabolol as a pro-apoptotic agent or that imatinib mesylate reduces the $\mathrm{IC}_{50}$ of $\alpha$-bisabolol. The imatinib mesylate-sensitive $\mathrm{BCR} / \mathrm{ABL}^{+} \mathrm{CML}-\mathrm{T} 1$ cell line, a T-cell lineage blast crisis of CML, was used in order to conclusively calculate the synergism, if any, between imatinib mesylate and $\alpha$-bisabolol. Figure 5B shows that the combination of imatinib mesylate and $\alpha$-bisabolol resulted in a higher degree of inhibition of cellular proliferation compared with each inhibitor alone $(p<0.05)$, and the combination was clearly synergistic, denoted by CI values $<1$ for any given $\mathrm{Fa}[16]$. Also, the combination resulted in a higher degree of induction of apoptosis (data not shown).

\section{$\alpha$-bisabolol and BID}

We have previously demonstrated that $\alpha$-bisabolol binds to the BCL-2 family member BID [3]. To evaluate the possibility that the treatment with $\alpha$-bisabolol leads to the cleavage of BID to truncated BID, we analyzed whole extract of leukemic cells and normal PBMCs by Western blot. As shown in Figure 6A, whereas truncated BID is detectable in the human T-cell lymphoblast-like cell line Jurkat used as a positive control, it is not present in PBMCs and blasts, indicating that the pro-apoptotic action of $\alpha$-bisabolol is not dependent on BID cleavage. However, caspase cleavage is not an absolute requirement for activating BID pro-apoptotic function. Full-length BID is also capable of translocation to the mitochondria, where it has been shown to potentiate cell death following certain apoptotic signals [20]. But we were unable to demonstrate full-length BID in the mitochondria by separating cytosolic and mitochondrial fraction following $\alpha$-bisabolol treatment (Figure 6B).

\section{Decrease of mitochondrial state 3 respiration}

In a previous paper, we confirmed the mitochondrial involvement in $\alpha$-bisabolol-induced cell death by the measurement of oxygen consumption by intact cells [21]. In the current work we used permeabilized leukemic cells from 6 patients ( $3 \mathrm{Ph}^{-} \mathrm{B}-\mathrm{ALL}, 1 \mathrm{Ph}^{+} \mathrm{B}$-ALL, 2AML) and healthy lymphocytes from 6 donors to determine whether $\alpha$-bisabolol treatment affects mitochondrial state 3 and uncoupled respiration. Figure $6 \mathrm{C}$ shows that NADH-supported state 3 respiration (G/M) in $\alpha$-bisabolol-treated leukemic cells was dramatically decreased in comparison with untreated leukemic controls $\left(140.0 \pm 70.5\right.$ vs. $280.7 \pm 11.9$ pmol $\mathrm{O}_{2} /$ minute $/ 10^{6}$ cells; $p<0.05)$. In contrast, the oxygen consumption sustained by S/G3P oxidation was not affected by $\alpha$ bisabolol treatment, and the mitochondrial respiration was not stimulated by the addition of FCCP. These data are in line with a loss of mitochondrial integrity in treated leukemic samples, which is responsible for the matrix NADH decrease. This behavior is confirmed by the observation that the respiration in the presence of S/G3P was unaffected. Healthy lymphocyte respiration was not statistically modified by $\alpha$-bisabolol treatment in state 3 using G/M and S/G3P as substrates and FCCP as a mitochondrial uncoupler. This is in agreement with the resistance to $\alpha$-bisabolol observed in lymphocytes (Figure 2A).

\section{Loss of mitochondrial potential}

JC-1 staining $[19,22]$ demonstrated that $\alpha$-bisabolol dissipates the mitochondrial transmembrane potential $\left(\Delta \Psi_{\mathrm{m}}\right)$. In fit cells, JC-1 is more concentrated in the mitochondria (driven there by the $\Delta \Psi_{\mathrm{m}}$ ), where it forms red-emitting aggregates, than in the cytosol, where it 
A

PBMC

ALL01 Jurkat

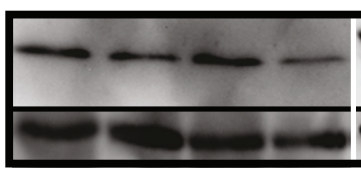

basal $\frac{20 \quad 40 \quad 80}{\mu \mathrm{M} \quad \alpha \text {-bisabolol }}$ basal $\frac{20 \quad 40 \quad 80}{\mu \mathrm{M} \alpha \text {-bisabolol }}$

B

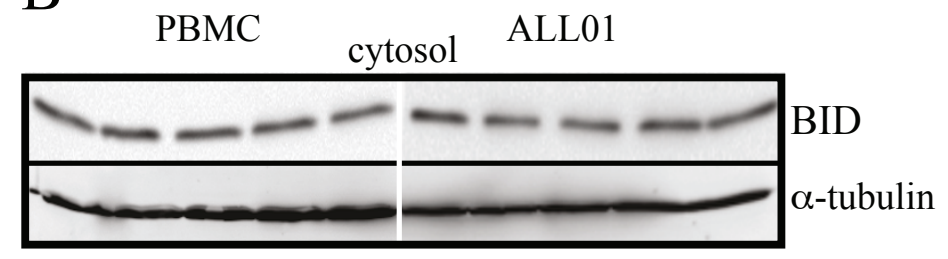

mitochondria

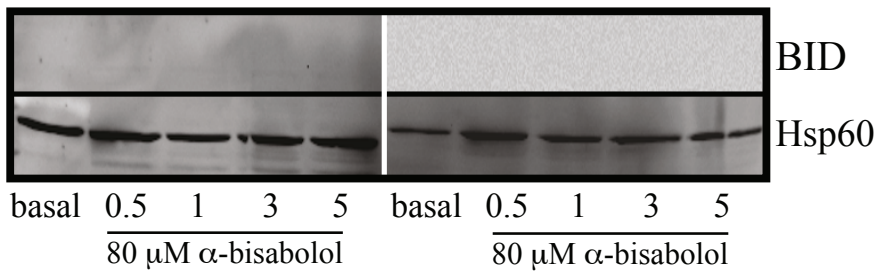

BID

tBID $\alpha$-tubulin

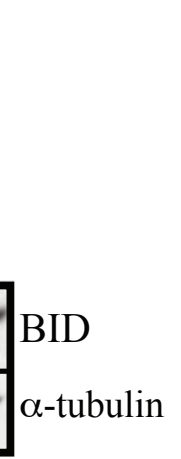

C

Figure 6 BID and NADH-supported state 3 respiration in normal PBMCs and leukemic blasts treated with $\alpha$-bisabolol. (A) 24-hour $\alpha$ bisabolol did not induced the cleavage of BID (full length $22 \mathrm{kDa}$, cleaved $15 \mathrm{kDa}$ ) at any concentration. Etoposide-treated Jurkat cells were used as a positive control for tBID. (B) No BID translocation was detected in mitochondrial fraction at different times and solubilized doses of $\alpha$ bisabolol. $\alpha$-tubulin and Hsp60 were used as markers for the cytosol and mitochondria fractions, respectively. A representative case is shown. (C) Permeabilized leukemic cells and healthy lymphocytes were incubated for 10 minutes in respiration buffer at $30^{\circ} \mathrm{C}$ in the presence or in the absence of $3 \mu \mathrm{M} \alpha$-bisabolol. In treated leukemic cells, the $\mathrm{G} / \mathrm{M}$ oxygen consumption was clearly lower than in untreated leukemic controls $(p<$ 0.05). The S/G3P oxygen consumption was not modified by treatment, and the mitochondrial respiration was not stimulated by FCCP addition. This is in line with a direct effect of $\alpha$-bisabolol on mitochondrial integrity. Healthy lymphocyte respiration was not affected by treatment. G/M: glutamate plus malate; S/G3P: succinate plus glycerol-3-phosphate; FCCP: carbonylcyanide-4-(trifluoromethoxy)-phenyl-hydrazone. Means \pm SD of 6 leukemias and 6 normal donors are depicted.

exists as a green-fluorescent monomer. Accordingly, the ratio red/green JC-1 fluorescence can be used as a sensitive measure of $\Delta \Psi_{\mathrm{m}}$ [23]. Disruption of $\Delta \Psi \mathrm{m}$ (a hallmark of cytochrome $c$ translocation and the start of the apoptotic process) is indicated by a loss of red fluorescence and an increase in green fluorescence. Figure 7A shows the representative case $\mathrm{Ph}{ }^{-} \mathrm{B}-\mathrm{ALL} \# 01$ out of the 6 tested. Microscopy revealed that in untreated leukemic cells well-polarized mitochondria were marked by punctate red fluorescent staining (Figure 7A, left side). After a 3-hour incubation with $40 \mu \mathrm{M} \alpha$-bisabolol, this pattern was replaced by diffuse green fluorescence in leukemic cells (Figure 7A, center and right side). Flow cytometry showed that untreated blasts with well-polarized, red-emitting mitochondria localized in the upper region of the plot (Figure 7A, left plot: high $\Delta \Psi_{\mathrm{m}}$ ). Blasts exposed to $40 \mu \mathrm{M} \alpha$-bisabolol underwent a progressive loss of red fluorescence, indicated by a shift right and downward over 3 (Figure 7A, central plot: intermediate $\Delta \Psi_{\mathrm{m}}$ ) and 5 hours (Figure 7A, right plot: low $\left.\Delta \Psi_{\mathrm{m}}\right)$. In contrast, normal lymphocytes used as a negative control did not suffer any changes in their microscopy or cytofluorimetric pattern when exposed to a similar $\alpha$-bisabolol concentration, indicating that there was no mitochondrial damage (Figure $7 \mathrm{~B}$, images and plots), and that the cells remained vital. Finally, the same blasts depicted in Figure 7A underwent PARP cleavage and DNA laddering following $\alpha$-bisabolol exposure (Figure $7 \mathrm{C}$ ).

\section{Discussion}

Forecasting the fraction of the lipophilic compound $\alpha$-bisabolol that was dissolved in water at given times was a basic preliminary step to standardize the drug use 


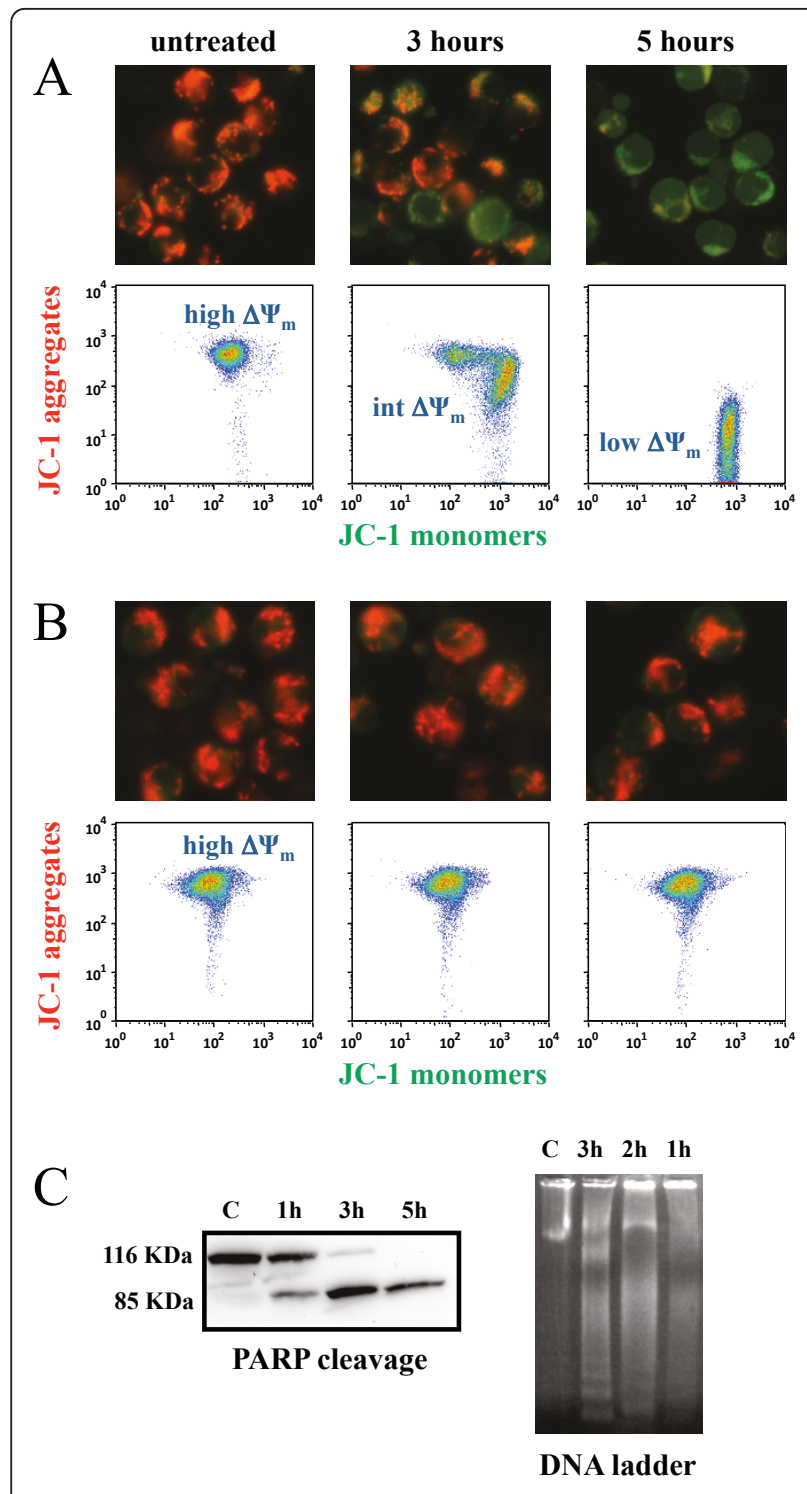

Figure $7 \alpha$-bisabolol-induced mitochondrial damage in primary leukemic blasts. Cells were stained with JC-1. In non-damaged cells, JC-1 forms red-emitting aggregates in the mitochondrial matrix. A loss of red fluorescence and an increase in cytoplasmic green-emitting monomers signal the disruption of the mitochondrial transmembrane potential $(\Delta \Psi \mathrm{m})$. (A) The representative case Ph-B-ALL \#01 is shown out of the 6 leukemias tested. Microscopy (magnification, $\times 400$ ). Whereas untreated leukemic blasts showed well-polarized mitochondria marked by punctated red fluorescent staining, blasts treated with $40 \mu \mathrm{M}$ $\alpha$-bisabolol had staining that was quite completely replaced by diffuse green fluorescence, indicating loss of $\Delta \Psi \mathrm{m}$. Flow cytometry. Untreated blasts with well-polarized mitochondria localized in the upper region of the plot (high $\Delta \Psi \mathrm{m}$ ). Blasts exposed to $40 \mu \mathrm{M}$ $\alpha$-bisabolol shifted right and downward (intermediate and low $\Delta \Psi \mathrm{m})$, due to the progressive dislocation of JC-1 from the mitochondria to the cytoplasm, which signaled the disruption of the mitochondrial $\triangle \Psi \mathrm{m}$. (B) Both untreated and $\alpha$-bisabolol-treated normal lymphocytes used as a negative control maintained wellpolarized mitochondria and did not undergo apoptosis. Apoptosis of leukemic blasts was also documented by (C) PARP cleavage and DNA laddering in the same representative case depicted in (A). in the conditions of our cytotoxicity tests. In these conditions, we and an independent analytical laboratory repeatedly measured that after 24 hours in culture medium $\alpha$-bisabolol lowered to around $65 \%$ of the theoretical concentrations added. In contrast, we could obtain only a $2.5 \%$ solubility fraction in previous studies [1]. Thus, the present experiments led to define conditions of maximal water solubility for $\alpha$-bisabolol.

By cluster analysis, we separated out three subgroups of leukemias with different sensitivities over 24 hours. $\alpha$-bisabolol was effective with an $\mathrm{IC}_{50}$ of $14 \pm 5 \mu \mathrm{M}$ in a substantial proportion of $\mathrm{Ph}^{-} \mathrm{B}-\mathrm{ALL}$, and with an $\mathrm{IC}_{50}$ of $45 \pm 7 \mu \mathrm{M}$ in a substantial proportion of both $\mathrm{Ph}^{+} \mathrm{B}-$ ALL and AML cases. Remarkably, these concentrations spared normal circulating leukocytes and $\mathrm{CD} 34^{+}$and CD $33^{+}$my hematopoietic bone marrow precursors. HUVECs, fibroblasts and hepatocytes were also spared (personal observation). The third subgroup included mainly, but not exclusively, AML samples with an $\mathrm{IC}_{50}$ value of $65 \pm 5 \mu \mathrm{M}$. Thus, $\mathrm{Ph}{ }^{-} \mathrm{B}$-ALL cases were definitely more sensitive than $\mathrm{AML}$ cases, whose $\mathrm{IC}_{50}$ was near to that observed in vitro also in normal leukocytes, except lymphocytes, and in hematopoietic precursors. Nevertheless, previous studies in animal models suggested that similar $\alpha$-bisabolol concentrations may be safely administered through daily oral supplementation even on a long-term basis $[24,25]$. The $\alpha$-bisabolol concentrations that we found active against leukemic cells in vitro are also lower than, or similar to, the concentrations that we measured in the blood and in the brains of healthy mice sacrificed after treatment with $1.4 \mathrm{~g} / \mathrm{Kg}$ $\alpha$-bisabolol. In these mice the blood parameters of liver and kidney fucntionality were preserved and, remarkably, the concentration in the brain exceeded $50 \mu \mathrm{M}$ without toxicity. Therefore, an active concentration of $\alpha$-bisabolol safely accumulated in a body environment where lymphoid blasts have a tendency to localize and survive protected from a number of curative drugs [26]. A dose of $10 \mathrm{mg} / \mathrm{mouse} \alpha$-bisabolol induced a decrease in the number of palpable mammary tumor masses without adverse reaction in HER-2 transgenic mice [2].

$\mathrm{Ph}^{+} \mathrm{B}$-ALL cells were also sensitive to $\alpha$-bisabolol. In three cases $\left(\mathrm{Ph}^{+} \mathrm{B}-\mathrm{ALL} \# 01, \# 04\right.$, \#06 in Table 1) with primary mutation of $\mathrm{BCR} / \mathrm{ABL}$, we observed a full efficacy of $\alpha$-bisabolol. In imatinib mesylate-sensitive blasts, the association of $\alpha$-bisabolol and imatinib mesylate led to a synergistic effect which we have conclusively calculated as a $\mathrm{CI}<1$ at any given $\mathrm{Fa}[16]$ in the $\mathrm{BCR} / \mathrm{ABL}^{+}$ human cell line CML-T1. It is not clear, however, whether the synergism depends on internalization mechanics or on intracellular modulation of the damaging actions of each or both drugs. A compound like $\alpha$-bisabolol - and others [27] - could help to identify profitable new strategies for both mutated and nonmutated leukemias $[9,28,29]$. 
Our biochemical data suggest a direct effect on mitochondrial integrity as a possible mechanism of $\alpha$-bisabolol damage to leukemic cells. This behavior is supported by the observed oxygen consumption decrease in the presence of glutamate/malate and by the unaffected respiration rates in the presence of succinate/glycerol-3phosphate. Microscopy and flow cytometry data show that $\alpha$-bisabolol disrupts $\Delta \Psi_{\mathrm{m}}$, which induces outer membrane permeabilization and leads to the apoptotic death of blasts. Our data not only implicate $\alpha$-bisabolol for the first time in mitochondrial impairment in human leukemic cells but also suggest that this goes through a peculiar model of cell death, i.e., the formation of a cellular population with intermediate $\mathrm{D} \Psi \mathrm{m}$ which is a feature of apoptosis seen only in a few cell types and never described to date in leukemic blasts [30].

In all leukemia samples treated with $\alpha$-bisabolol, BID was found to be expressed in a full-lenght form that was suitable for binding to $\alpha$-bisabolol. We failed to demonstrate full-length BID translocation to the mitochondria in leukemic cells as a pro-apoptotic mechanism [19]. Nevertheless, BID might act as a carrier that conveys $\alpha$ bisabolol to the mitochondrial membrane.

Thus, according to our previous and present work, $\alpha$ bisabolol enters cells via lipid rafts and directly involves mitochondrial permeability transition pore opening [20], which is responsible for the reduced glutamate/malatesupported oxygen consumption and leads to disruption of the mitochondrial membrane potential and programmed cell death. The reciprocal role of BID and $\alpha$ bisabolol [3] remains elusive in leukemic cells.

\section{Conclusion}

We provide here the first evidence that $\alpha$-bisabolol is an effective pro-apoptotic agent in primary ALL cells at concentrations and durations that spare normal blood and bone marrow cells. It retains cytotoxic potential in both imatinib mesylate-resistant and -sensitive $\mathrm{Ph}^{+} \mathrm{B}$ ALL. It is also active against primary AML cells at slightly higher concentrations. Our findings support $\alpha$ bisabolol as a possible candidate for the treatment of acute leukemias and establish a basis for studies in animal models.

\footnotetext{
Acknowledgements

The authors thank mathematics professor Vincenza Tomasello for her criticism and advice on numerical analysis and appreciate that she is surely a firm believer in Plato's "Let nobody ignorant of geometry enter here". This work was supported by grants from the Venetian Institute of Oncology (IOV), Padua (Italy) and from Fondazione Cariverona, Verona (Italy).
}

\section{Author details}

${ }^{1}$ Department of Sciences of Life and Reproduction, Section of Biochemistry, University of Verona, Italy. ${ }^{2}$ Department of Medicine, Section of Hematology, University of Verona, Italy. 'Department of Biochemistry "G. Moruzzi",

University of Bologna, Italy.

\section{Authors' contributions}

$E C, A R, A C d P$ performed the research, analyzed data, and performed statistical analysis; MB, EG, CB, RF contributed analytical tools, performed selected experiments and analyzed data; GP contributed criticism; HS suggested the research, contributed ideas and critical scientific knowledge analyzed and interpreted data; FV chose the clinical setting, designed and performed the research, analyzed and interpreted data, and wrote the paper; all authors checked the final version of the manuscript.

\section{Competing interests}

The authors declare that they have no competing interests.

Received: 18 November 2010 Accepted: 21 April 2011

Published: 21 April 2011

\section{References}

1. Cavalieri E, Mariotto S, Fabrizi C, De Prati AC, Gottardo R, Leone S, Berra LV, Lauro GM, Ciampa AR, Suzuki H: a-bisabolol, a non-toxic natural compound, strongly induces apoptosis in glioma cells. Biochem Biophys Res Commun 2004, 315:589-594.

2. Costarelli L, Malavolta M, Giacconi R, Cipriano C, Gasparini N, Tesei S, Pierpaoli S, Orlando F, Suzuki H, Perbellini L, Piacenza F, Emanuelli M, Mocchegiani E: In vivo effect of alpha-bisabolol, a nontoxic sesquiterpene alcohol, on the induction of spontaneous mammary tumors in HER-2/neu transgenic mice. Oncol Res 2010, 18:409-418.

3. Darra E, Abdel-Azeim S, Manara A, Shoji K, Marechal JD, Mariotto S, Cavalieri E, Perbellini L, Pizza C, Perahia D, Crimi M, Suzuki H: Insight into the apoptosis-inducing action of a-bisabolol towards malignant tumor cells: Involvement of lipid rafts and Bid. Arch Biochem Biophys 2008, 476:113-123.

4. Tallman MS, Gilliland DG, Rowe JM: Drug therapy for acute myeloid leukemia. Blood 2005, 106:1154-1163.

5. Appelbaum FR, Rosenblum D, Arceci RJ, Carroll WL, Breitfeld PP, Forman SJ, Larson RA, Lee SJ, Murphy SB, O'Brien S, Radich J, Scher NS, Smith FO, Stone RM, Tallman MS: End points to establish the efficacy of new agents in the treatment of acute leukemia. Blood 2007, 109:1810-1816.

6. Lancet JE, Giralt S: Therapy for older AML patients: the role of novel agents and allogeneic stem cell transplant. J Natl Compr Canc Netw 2008, 6:1017-1025.

7. Kohrt HE, Coutre SE: Optimizing therapy for acute myeloid leukemia. J Natl Compr Canc Netw 2008, 6:1003-1016.

8. Bradeen HA, Eide CA, O'Hare T, Johnson KJ, Willis SG, Lee FY, Druker BJ, Deininger MW: Comparison of imatinib mesylate, dasatinib (BMS354825), and nilotinib (AMN107) in an N-ethyl-N-nitrosourea (ENU)based mutagenesis screen: high efficacy of drug combinations. Blood 2006, 108:2332-2338

9. Cortes J, Rousselot P, Kim DW, Ritchie E, Hamerschlak N, Coutre S, Hochhaus A, Guilhot F, Saglio G, Apperley J, Ottmann O, Shah N, Erben P, Bradford S, Agarwal P, Gollerkeri A, Baccarani M: Dasatinib induces complete hematologic and cytogenetic responses in patients with imatinib-resistant or intolerant chronic myeloid leukemia in blast crisis. Blood 2007, 109:3207-3213.

10. Todeschini G, Tecchio C, Meneghini V, Pizzolo G, Veneri D, Zanotti R, Ricetti MM, Solero P, Aprili F, Perona G: Estimated 6-year event-free survival of $55 \%$ in 60 consecutive adult acute lymphoblastic leukemia patients treated with an intensive phase II protocol based on high induction dose of daunorubicin. Leukemia 1998, 12:144-149.

11. Vitale A, Guarini A, Ariola C, Mancini M, Mecucci C, Cuneo A, Pane F, Saglio G, Cimino G, Tafuri A, Meloni G, Fabbiano F, Recchia A, Kropp MG, Krampera M, Cascavilla N, Ferrara F, Romano A, Mazza P, Fozza C, Paoloni F, Vignetti M, Foà R: Adult T-cell acute lymphoblastic leukemia: biologic profile at presentation and correlation with response to induction treatment in patients enrolled in the GIMEMA LAL 0496 protocol. Blood 2006, 107:473-479.

12. Ratei R, Basso G, Dworzak M, Gaipa G, Veltroni M, Rhein P, Biondi A, Schrappe M, Ludwig WD, Karawajew L, for the AIEOP-BFM-FCM-MRD-Study Group: Monitoring treatment response of childhood precursor B-cell acute lymphoblastic leukemia in the AIEOP-BFM-ALL 2000 protocol with multiparameter flow cytometry: predictive impact of early blast reduction on the remission status after induction. Leukemia 2009, 23:528-534. 
13. Vinante F, Rigo A, Papini E, Cassatella MA, Pizzolo G: Heparin-binding epidermal growth factor-like growth factor/diphtheria toxin receptor expression by acute myeloid leukemia cells. Blood 1999, 93:1715-1723.

14. Vinante F, Marchi M, Rigo A, Scapini P, Pizzolo G, Cassatella MA: Granulocyte-macrophage colony-stimulating factor induces expression of heparin-binding epidermal growth factor-like growth factor/ diphtheria toxin receptor and sensitivity to diphtheria toxin in human neutrophils. Blood 1999, 94:3169-3177.

15. Gratama JW, Keeney M, Sutherland DR: Enumeration of CD34+ hematopoietic stem and progenitor cells. In Current Protocols in Cytometry. Edited by: Robinson JP, Darzynkiewicz Z, Dean PN, Dressler LG, Rabinovitch PS, Stewart CC, Tanke HJ, Wheeless LL. New York: John Wiley 1999:, 6.4.1-22

16. Chou T-C, Talalay P: Quantitative analysis of dose-effect relationships: the combined effects of multiple drugs or enzyme inhibitors. Adv Enzyme Regul 1984, 22:27-55.

17. Chretien D, Bénit P, Chol M, Lebon S, Rötig A, Munnich A, Rustin P: Assay of mitochondrial respiratory chain complex I in human lymphocytes and cultured skin fibroblasts. Biochem Biophys Res Commun 2003, 301:222-224.

18. Nougayrède JP, Donnenberg MS: Enteropathogenic Escherichia coli EspF is targeted to mitochondria and is required to initiate the mitochondrial death pathway. Cell Microbiol 2004, 611:1097-1111.

19. Troiano L, Ferraresi R, Lugli E, Nemes E, Roat E, Nasi M, Pinti M, Cossarizza A Multiparametric analysis of cells with different mitochondrial membrane potential during apoptosis by polychromatic flow cytometry. Nat Protoc 2007, 2:2719-2727.

20. Zinkel S, Gross A, Yang E: BCL2 family in DNA damage and cell cycle control. Cell Death and Differentiation 2006, 13:1351-1359.

21. Cavalieri E, Bergamini C, Mariotto S, Leoni S, Perbellilni L, Darra E, Suzuki H, Fato R, Lenaz G: Involvement of mitochondrial permeability transition pore opening in alpha-bisabolol induced apoptosis. FEBS J 2009, 276:3990-4000.

22. Galluzzi L, Zamzami N, de La Motte Rouge T, Lemaire C, Brenner C, Kroemer G: Methods for the assessment of mitochondrial membrane permeabilization in apoptosis. Apoptosis 2007, 12:803-813.

23. Métivier D, Dallaporta B, Zamzami N, Larochette N, Susin SA, Marzo I, Kroemer G: Cytofluorometric detection of mitochondrial alterations in early CD95/Fas/APO-1-triggered apoptosis of Jurkat T lymphoma cells. Comparison of seven mitochondrion-specific fluorochromes. Immunol Lett 1998, 61:157-163.

24. Bhatia SP, McGinty D, Letizia CS, Api AM: Fragrance Material Review on abisabolol. Food Chem Toxicol 2008, 46(Suppl 11):S72-S76.

25. Kamatou GPP, Viljoen AM: A review of the application and pharmacological properties of a-bisabolol and a-bisabolol-rich oils. J Am Oil Chem Soc 2009, 28:1-7.

26. Stanulla M, Schrappe M: Treatment of childhood acute lymphoblastic leukemia. Semin Hematol 2009, 46:52-63.

27. Zhang H, Trachootham D, Lu W, Carew J, Giles FJ, Keating MJ, Arkinghaus RB, Huang P: Effective killing of Gleevec-resistant CML cells with T315I mutation by a natural compound PEITC through redoxmediated mechanism. Leukemia 2008, 22:1191-1199.

28. Druker BJ: Circumventing resistance to kinase-inhibitor therapy. N Engl J Med 2006, 354:2594-2596.

29. Talpaz M, Shah NP, Kantariian H, Donato N, Nicoll J, Paquette R, Cortes J, O'Brien S, Nicaise C, Bleickardt E, Blackwood-Chirchir MA, lyer V, Chen TT, Huang F, Decillis AP, Sawyers CL: Dasatinib in imatinib-resistant Philadelphia chromosome positive leukemias. N Engl J Med 2006, 354:2531-2541.

30. Lugli E, Troiano L, Ferraresi R, Roat E, Prada N, Nasi M, Pinti M, Cooper EL, Cossarizza A: Characterization of cells with different mitochondrial membrane potential during apoptosis. Cytometry 2005, 68:28-35.

doi:10.1186/1479-5876-9-45

Cite this article as: Cavalieri et al:: Pro-apoptotic activity of $\alpha$-bisabolol in preclinical models of primary human acute leukemia cells. Journal of Translational Medicine 2011 9:45.

\section{Submit your next manuscript to BioMed Central and take full advantage of:}

- Convenient online submission

- Thorough peer review

- No space constraints or color figure charges

- Immediate publication on acceptance

- Inclusion in PubMed, CAS, Scopus and Google Scholar

- Research which is freely available for redistribution

Submit your manuscript at www.biomedcentral.com/submit
Biomed Central 